\title{
PENDAMPINGAN APLIKASI TEKNIS MARKETPLACE PADA UMKM GUNA MEMPERMUDAH DALAM PEMASARAN PRODUK SECARA ONLINE
}

\author{
Anggun Anggraini, Indawati, Lindawati., \\ Siti Hanah, Wulandari Cahyani Putri \\ Dosen Ekonomi Fakultas Ekonomi Universitas Pamulang \\ Email: dosen02156@unpam.ac.id,dosen02151@unpam.ac.id,dosen02248@unpam.ac.id, \\ dosen01609@unpam.ac.id, dosen02274@unpam.ac.id
}

\begin{abstract}
ABSTRAK
Tujuan dari Kegiatan Pengabdian Kepada Masyarakat adalah untuk melaksanakan salah satu Tri Dharma Perguruan Tinggi. Selain itu diharapkan dengan pengabdian kepada masyarakat tersebut keberadaan perguruan tinggi dapat memberikan kontribusi besar kepada pengembangan dan penerapan keilmuan kepada masyarakat.

Metode pelaksanaan pengabdian ini dilakukan dalam beberapa kegiatan yaitu tahap survei yaitu sosialisasi dilakukan dengan menyusun berbagai hal yang akan disampaikan pada saat kegiatan pengabdian yang akan dilakukan yang meliputi: penyusunan materi yang akan diberikan, penyusunan jadwal pemberian materi, pembagian tugas tim pengabdian dan survei ke lokasi pengabdian. Tahap sosialisasi yaitu sebelum kegiatan pengabdian dilaksanakan terlebih dahulu dilakukan tahap sosialisasi yaitu melakukan silaturahmi dengan RPM dimana UMKM yang di bina kali ini adalah Ibu Henny pemilik pempek karakter, menyampaikan maksud dan tujuan pengabdian ini. Pada tahap ini juga dilakukan jalinan kerjasama dan menentukan jadwal kegiatan pengabdian. Tim pelaksana kegiatan pengabdian pada masyarakat adalah dosen Fakultas Ekonomi jurusan akuntansi sebanyak 5 orang dosen dan 1 orang mahasiswa. Tim pengabdian memberikan materi tentang pendampingan aplikasi teknis marketplace pada UMKM guna mempermudah dalam pemasaran produk secara online.

Hasil pengabdian masyarakat yang diperoleh adalah bertambahnya keilmuan bagi Ibu Henny selaku UMKM Binaan yang dibantu oleh RPM dalam proses pemasaaran produk dengan memiliki akun marketplace bertujuan untuk mempermudah dalam proses pemasaran produk dengan menggunakan aplikasi shopee dalam hal memasarkan produk. Ilmu yang diperoleh pada Pengabdian Masyarakat kali ini diharapkan mampu memberikan semangat baru bagi kita dalam menyampaikan materi dan motivasi serta berkontribusi khususnya bagi UMKM.
\end{abstract}

\section{Kata Kunci: UMKM, Marketplace, Shopee}

\begin{abstract}
ABSTRAC
The purpose of Community Service Activities is to carry out one of the Tri Dharma of Higher Education. In addition, it is hoped that with this community service, the existence of universities can make a major contribution to the development and application of science to the community.

The method of implementing this service is carried out in several activities, namely the survey stage, namely the socialization is carried out by arranging various things that will
\end{abstract}




\section{JURNAL ABDIMAS

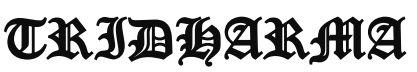

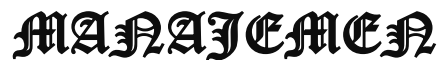

P-ISSN 2715-7105, E-ISSN 2716-070X

Jurnal ABDIMAS Vol. 2, No. 1, Januari 2021,Hal (96-102)

@Prodi Manajemen Fakultas Ekonomi Universitas Pamulang

Email: abdimasjurnal.unpam@ gmail.com Telp: (021) 741-2566

be conveyed during the service activities that will be carried out which include: preparation of the material to be given, preparation of a schedule for providing material, division of tasks for the service team and surveying the location devotion. The socialization stage, namely before the service activity is carried out, the socialization stage is carried out first, namely conducting a friendship with RPM where the UMKM being coached this time are Mrs. Henny, the owner of Pempek Character, conveying the aims and objectives of this service. At this stage, cooperation is also carried out and determines a schedule of service activities. The team for implementing community service activities are 5 lecturers of the Faculty of Economics, majoring in accounting, and 1 student. The service team provides material about marketplace technical application assistance to UMKM in order to facilitate online product marketing.

The results of community service obtained are increased knowledge for Ms. Henny as the Assisted UMKM under the auspices of RPM in the product marketing process by having a marketplace account which aims to facilitate the product marketing process by using the Shopee application in terms of marketing products. The knowledge obtained at this Community Service is expected to be able to provide new enthusiasm for us in conveying material and motivation and contributing especially to UMKM.

\section{Keywords: UMKM, Marketplace, Shopee}

\section{PENDAHULUAN}

Di Kota Tangerang Selatan khususnya, para pelaku UKM banyak dibantu oleh Rumah Pemberdayaan Masyarakat (RPM). Rumah Pemberdayaan Masyarakat adalah sebuah lembaga nirlaba yang berfokus pada pelatihan dan pendampingan dalam berbagai programprogram pemberdayaannya. Selain itu, dalam setiap program Rumah Pemberdayaan Masyarakat menekankan kepada penguasaan bidang Digital. Kenapa harus Digital? karena saat ini dunia menuju kehidupan yang serba otomatis, manusia mulai tergantikan oleh mesin, software dan peralatan lainnya yang dapat bekerja 24 jam tanpa istirahat sebagaimana manusia yang ada batasnya dalam bekerja. Dengan alasan itu maka penguasaan akan digital marketing sangat ditekankan untuk memenangi persaingan di dunia nyata baik tingkat lokal maupun internasional.

Kota Tangerang Selatan yang memiliki luas wilayah $147,19 \mathrm{Km} 2$ atau 14.719 Ha memiliki potensi kreatif ekonomi yang sangat baik. Jumlah usaha menurut kategori lapangan usaha yang terbanyak adalah usaha perdagangan, yaitu sebesar 44.196 jenis usaha atau 41,78 persen dengan penyerapan tenaga kerja sebesar 109.456 orang. Dari banyaknya jenis usaha perdagangan di kota Tangerang Selatan, Rumah pemberdayaan masyarakat menggolongkan UMKM berdasarkan lamanya usaha perdagangan dan minimal omset. Untuk jenis usaha perdagangan dengan kategori minimal usaha 2 tahun dan dengan omset minimal lima juta sebulan, digolongkan sebagai kategori UMKM Scale Up

Peningkatan sektor potensi perekonomian daerah dilakukan dengan penggiatan kegiatan Usaha Menengah Kecil Mikro (UMKM). Penggiatan UMKM didasarkan karena adanya pandemi covid-19, dimana banyak Sebagian masyarakat yang terkena PHK dan beralih membuka usaha dengan lingkup mikro. Karena adanya pandemi ini merubah cara pandang masyarakat Kota Tangerang Selatan yang dikenal memiliki sifat konsumtif mulai bertransformasi menjadi lebih produktif. Sebelum adanya pandemi pekerjaan yang dianggap layak adalah pegawai. Wirausaha yang dahulu tabu dilakukan oleh masyarakat Kota Tangerang Selatan kini mulai digeluti baik itu oleh masyarakat biasa maupun pegawai. Sehingga pertumbuhan UMKM Kota Tangerang Selatan mengalami peningkatan. 
Kehadiran e-commerce dinilai memberikan manfaat besar bagi kalangan masyarakat, utamanya bagi pelaku usaha mikro kecil dan menengah (UMKM). Hingga kuartal ketiga tahun ini, I-Price mencatat sebanyak 50 perusahaan $e$ commerce atau toko online yang bersaing di Indonesia. Selain memberikan kemudahan transaksi jual beli, $e$ commerce diharapkan membantu pelaku UMKM dengan menjamin harga yang lebih murah, ketersediaan produk, akses logistik dan kemudahan akses pembiayaan. Kemudahan-kemudahan itu ternyata dinikmati pemilik katering Dapoer Doro dari B2B marketplace. Menurut Ahyuna, et al., (2013), pelaku usaha merasakan manfaat yang sangat besar dengan menggunakan media internet dibandingkan secara kovensional, karena dapat mengurangi jumlah biaya dan waktu yang dikeluarkan dalam proses penjualan. Pemanfaatan internet ini untuk usaha melalui advertising, sales promotion, direct marketing, dan personal selling terhadap produk-produk mereka di internet karena dapat melakukan pemasaran secara cepat. Selain itu, internet juga merupakan media yang efektif sebagai media promosi karena dapat mempengaruhi seseorang untuk melakukan pembelian. Dengan melakukan promosi online dengan baik, maka akan meningkatkan minat seseorang untuk melakukan keputusan pembelian dan serta menciptakan persepsi harga yang sesuai dengan produk yang di tawarkan (Jamaludin, et. al., 0215). Keuntungan dan kemudahan lain dari internet sebagai media marketplace menurut Jamaludin, et. al., (0215) adalah toko online biasanya yaitu tersedia 24 jam sehari, dan banyak konsumen memiliki akses internet baik dalam pekerjaan maupun di rumah. Karena jika melakukan kunjungan ke toko ritel konvensional membutuhkan perjalanan dan harus berlangsung selama jam kerja. Maka denga mencari atau menelusuri sebuah katalog online dapat lebih cepat.
Internet juga dapat dimanfaatkan oleh usaha dengan skala mikro atau kecil. Baik untuk promosi maupun penjualan. Karena selain biayanya yang cukup murah juga mudah dilakukan serta tidak tergantung oleh waktu. Beberapa media internet yang dapat dimanfaatkan oleh pelaku UMKM adalah website, sosial media (facebook, Instagram, dll), atau marketplace seperti bukalapak.com, tokopedia.com, dan lain-lain. Bahkan dengan kehadiran banyak media di internet yang dapat dimanfaatkan sebagai media bisnis, pelaku usaha kini tidak perlu lagi memiliki tempat (outlet) atau tempat untuk berjualan yang membutuhkan biaya tinggi.

Berdasarkan pengamatan langsung terhadap pelaku usaha skala mikro dan kecil belum sepenuhnya bahkan sama sekali belum memanfaatkan media internet sebagai media promosi maupun penjualan. Padahal kemudahan dalam mengakses berbagai media sosial merupakan peluang untuk menunjang meningkatkan penjualan usaha karena produk akan lebih dikenali oleh masyarakat, sehingga dapat meningkatkan kemungkinan terjadinya transaksi. Selain itu manfaat lain yang didapatkan dari media internet menurut Mahedy, et. al,. (2016) diantaranya masyarakat dapat mengetahui produk yang ditawarkan dengan mudah, bagi calon pembeli dapat melakukan perbandingan dengan produk lain sebelum melakukan transaksi pembelian, peluncuran atau promosi produk baru bisa dilakukan seefektif mungkin, meminimalkan biaya promosi, dan jangkauan pasar atau pangsa menjadi tak terbatas karena bisa diakses darimana saja dan oleh siapa saja. Bahkan dengan kehadiran banyak media di internet yang dapat dimanfaatkan sebagai media bisnis, pelaku usaha kini tidak perlu lagi memiliki tempat (outlet) atau tempat untuk berjualan yang membutuhkan biaya tinggi.

\section{RUMUSAN MASALAH}

Dengan mempertimbangkan latar belakang yang telah dijelaskan diatas kami 


\section{JURNAL ABDIMAS

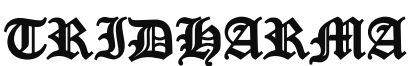 AIA}

berinisiatif untuk membentuk pengabdian masyarakat bagi UMKM yang dibantu oleh RPM khususnya dalam program Pendampingan Aplikasi Teknis Marketplace Pada UMKM Guna Mempermudah dalam Pemasaran Produk Secara Online.

\section{TUJUAN PELAKSANAAN}

1. Mempermudah dalam pemasaran produk online dengan menggunakan marketplace.

\section{TINJAUAN PUSTAKA}

Peningkatan daya saing yang terjadi saat ini sangat ketat, dengan adanya bantuan Teknologi Informasi dan Komunikasi dapat berjalan mudah dengan menggunakan media internet sebagai bantuan melakukan aktivitas. Penelitian yang dikembangkan oleh (Sadgotra \& Saputra, 2013) menciptakan suatu wadah atau media untuk melakukan usaha secara online (marketplace) berbasis website. Pada website yang telah dikembangkan untuk melakukan Usaha Kecil dan Menengah (UKM) yang dapat menangani segala proses transaksi yang dilakukan secara online.

Proses jual beli dapat dilakukan lebih mudah, bagi penjual, mereka dapat dengan mudah mempromosikan barang yang dijual dan bagi pihak konsumen dapat dengan mudah menemukan barang yang dibutuhkan. Faktor yang mempercepat terjadinya transaksi tersebut adalah kebanyakan perusahaan sudah menggunakan e-marketplace yang memungkinkan bertemunya penjual dan pembeli dalam melakukan transaksi. Pada penelitian ini membuat aplikasi website untuk melakukan promosi penjualan barang yang dimiliki oleh penjual dan dapat melakukan tukar menukar informasi antara penjual dan pembeli (Kodong, et al., 2012).

Marketplace merupakan media online berbasis internet (web based) tempat melakukan kegiatan bisnis dan transaksi antara pembeli dan penjual.
Pembeli dapat mencari supplier sebanyak mungkin dengan kriteria yang diinginkan, sehingga memperoleh sesuai harga pasar. Sedangkan bagi supplier/penjual dapat mengetahui perusahaan-perusahaan yang membutuhkan produk/jasa mereka (Opiida, 2014). Marketplace merupakan model E-Business yang berhubungan dengan penjual dan pembeli (seller \& buyer). Marketplace di Indonesia merupakan salah satu media penggerak ekonomi nasional dalam rangka menghadapi era globalisasi. Untuk itu, perlu dikembangkan Marketplace yang teratur, wajar dan efisien. Pada umumnya Marketplace yang efisien dapat meningkatkan iklim investasi di perusahaan dan memudahkan arus input dan output barang.

Nufransa (2014) Online marketplace adalah situs yang disediakan oleh penyelenggara jasa internet kepada para penjual untuk dapat menjajakan daganganya melalui dunia maya. Ruang (space) yang disediakan oleh penyedia jasa internet berbentuk laman situs yang disediakan kepada para penjual. Pembeli dapat melihat berbagai macam etalase online yang berada di situs online yang berada di situs online market place.Tempat berkumpulnya penjual dan pembeli ini layaknya pusat perbelanjaan biasa, hanya semuanya terselenggara di dunia maya.

Situs ini berisi berbagai macam penjual dengan berbagai macam barang dagangan yang menyewa tempat dari penyelenggara jasa internet. Contoh dari kategori ini adalah shopee, tokopedia.com, rakuten.com, bukalapak.com, duniavirtual.com. pengelola situs ini menyewa ruang (space) dalam situs mereka yang digunakan untuk berdagang bagi para penjual.

Pada umumnya perusahaan atau pelaku usaha dalam menjalankan kegiatan usahanya tentu berkeinginan untuk membuat produknya laku terjual. Dalam hal ini, perusahaan akan menghadapi persaingan yang ketat, sehingga perlu melakukan strategi pemasaran yang tepat. 


\section{JURNAL ABDIMAS

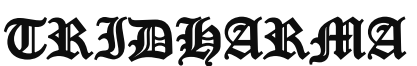 AIA}

P-ISSN 2715-7105, E-ISSN 2716-070X

Jurnal ABDIMAS Vol. 2, No. 1, Januari 2021,Hal (96-102)

@Prodi Manajemen Fakultas Ekonomi Universitas Pamulang

Email: abdimasjurnal.unpam@ gmail.com Telp: (021) 741-2566
Menurut Kotler dan Keller (2012) Pemasaran merupakan kegiatan yang bertujuan untuk menciptakan pasar akan suatu produk. Strategi pemasaran atau bauran pemasaran (marketing mix) meliputi 4 hal, yaitu: Product, Price, Place, Promotion. Contoh strategi pemasaran konvensional yang diterapkan dari dulu hingga sekarang misalnya iklan, direct marketing, dan sales promotion. Ketiga contoh tersebut bukan berarti tidak bermanfaat lagi di masa sekarang, namun perusahaan tentunya perlu mempertimbangkan media baru dan strategi baru agar pemasaran menjadi lebih efektif dan efisien.

Masalah yang sampai saat ini masih perlu diperhatikan adalah kurangnya kesadaran masyarakat atau pengusaha untuk memanfaatkan media digital sebagai sarana untuk mengembangkan kegiatannya. Dengan produk yang relatif sudah cukup bagus, bila pasar yang dijangkau terbatas maka tidak akan cukup untuk menolong kelangsungan hidup perusahaan itu sendiri. Karena itu diperlukan langkah-langkah atau strategi mengatasi masalah pemasaran tersebut, salah satunya dengan memanfaatkan media digital. Dewasa ini sudah saatnya pelaku usaha mempersiapkan diri untuk memasuki era baru dalam dunia pemasaran. Sebab selama ini, kelemahan menentukan strategi pemasaran yang efektif dan efisien menjadi persoalan bagi hampir seluruh pelaku usaha di tanah air.

Media digital kini menjadi media penting yang digunakan di setiap kalangan masyarakat. Menurut Widiarto (2016) penguna internet di Indonesia sebesar 132,7 juta jiwa dan menjadi negara terbesar kedua dalam penggunaan aplikasi Facebook di dunia. Media digital tumbuh pesat seiring dengan bertambahnya pengguna internet di kawasan Asia Tenggara. Media digital pun bahkan sudah menjadi gaya hidup modern, di samping itu penggunaan media digital telah banyak membantu setiap orang dalam melakukan rutinitas. Individu, organisasi, bahkan pemerintahan juga tidak pernah terlepas dari aktifitas menggunakan media digital. Contoh media digital yang sering digunakan saat ini, yaitu : Facebook, Twitter, Path, Instagram, dan YouTube. Masing-masing media digital tersebut mempunyai fungsi yang sama, yaitu untuk berkomunikasi.

Banyaknya kemudahan dan fungsi dari penggunaan media digital, mendorong masyarakat atau pengusaha di dunia, untuk memaanfaatkan media digital tersebut pada setiap kegiatannya. Fungsi lain dari penggunaan media digital meliputi : branding, sharing, promosi, maupun marketing. Perkembangan teknologi informasi dan internet juga berpengaruh besar terhadap perkembangan di bidang promosi produk. Hal tersebut tentunya sangat menguntungkan bagi dunia promosi produk karena kemudian terjadi peningkatan efektivitas jika dibandingkan dengan media konvensional. Aspek utama yang mempengaruhi peningkatan efektivitas promosi produk melalui internet adalah media yang interaktif, bersifat fleksibel dengan pengertian adanya pertukaran pesan dua arah dan media yang responsif

Mengingat pada jaman sekarang perdagangan dilakukan secara online dengan memanfaatkan media smartphone maupun komputer dengan tujuan menjangkau pasar lebih luas lagi baik pasar nasional maupun internasional. Selain itu, perdagangan secara online juga memudahkan pembeli dalam bertransaksi dan mendapatkan barang sehingga saat ini perdagangan online lebih diminati masyarakat daripada berbelanja ke toko.

\section{HASIL DAN PEMBAHASAN}

Kegiatan Pengabdian Masyarakat Universitas Pamulang yang dilakukan oleh dosen-dosen program studi Akuntansi telah berjalan dengan lancar dan mendapat sambutan hangat oleh UMKM yang dibantu oleh RPM dengan menggunakan aplikasi zoom meeting. 


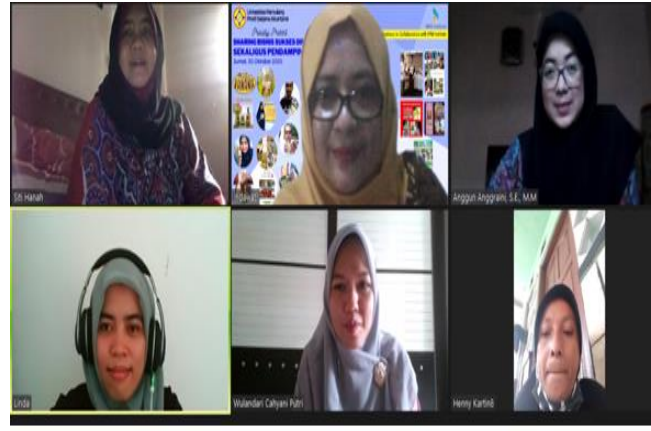

Harapan kami dengan pengabdian ini adalah membantu UMKM khususnya Ibu Henny dalam proses memasarkan produk secara online dengan menggunakan marketplace shopee.

\section{KESIMPULAN DAN SARAN Kesimpulan}

Dari paparan yang sudah kami bahas diatas, berikut adalah kesimpulan yang dapat dipaparkan:

1. Pelaksanaan kegiatan Pengabdian Kepada Masyarakat yang dilakukan oleh dosen-dosen program studi Akuntansi telah berjalan dengan lancar dan mendapat sambutan hangat dari tempat pelaksanaan kegiatan ini yaitu UKM yang dibantu oleh RPM (Rumah Pemberdayaan Masyarakat) Tema/Judul yang akan disampaikan dalam pengabdian kepada masyarakat ini yaitu "Pendampingan Aplikasi Teknis Marketplce Pada UMKM Guna Mempermudah Dalam Pemasaran Produk Secara Online".

2. Pelaksanaan sosialisasi pemasaran online telah memenuhi luaran yang ditargetkan, yaitu terjadi peningkatan pemahaman mengenai pentingnya pemasaran secara online, sehingga setelah sosialisasi diberikan, peserta dapat menjelaskan pentingnya pemasaran online. Selain itu, mitra juga sangat tertarik untuk mulai melakukan pemasaran secara online.

3. Program pelatihan pembuatan dan penggunaan akun shopee telah mengalami peningkatan. Dengan diselenggarakan serangkaian program, maka mitra diharapkan dapat meningkatkan keuntungan dan mengembangkan kegiatan usahanya lebih baik lagi di masa mendatang.

\section{Saran}

Adapun saran yang dapat disampaikan untuk peningkatan kegiatan selanjutnya, yaitu karena biaya yang didanai terbatas, maka belum dapat menjangkau Peserta dalam kuantitas lebih banyak dan waktu pelatihan dilakukan secara singkat, sehingga diharapkan adanya penambahan dana agar program dapat dilaksanakan dengan melibatkan peserta yang lebih banyak dan waktu yang memadai. Adapun rencana program selanjutnya dengan mitra yang sama akan diselenggarakan program sosialisasi dan pelatihan pembuatan merek beserta regulasinya..

\section{DAFTAR PUSTAKA}

Adipranata R., Theresia L, Santi W., E Market place Sebagai Sarana Transasi Lelang Online, Skripsi, Universitas Kristen Petra

Ahyuna, Hamzah, M., D., dan Najib, M., 2013. Pemanfaatan Internet Sebagai Media Promosi Pemasaran Produk Lokal Oleh Kalangan Usaha Di Kota Makassar. Jurnal Komunikasi KAREBA Vol. 2, No.1 Januari Maret 2013, 30-40

Hartanto, AAT , 2010, Panduan Aplikasi Smartphon, Jakarta: Gramedia Pustaka Utama. ISBN 1006762-33-5. Jamaludin, A., Arifin, Z., dan Hidayat, K., 2015. Pengaruh Promosi Online Dan Persepsi Harga Terhadap Keputusan Pembelian (Survei Pada Pelanggan Aryka Shop di Kota Malang).Jurnal 


\section{JURNAL ABDIMAS

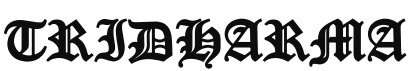 AIA}

P-ISSN 2715-7105, E-ISSN 2716-070X

Jurnal ABDIMAS Vol. 2, No. 1, Januari 2021,Hal (96-102)

@Prodi Manajemen Fakultas Ekonomi Universitas Pamulang

Email: abdimasjurnal.unpam@ gmail.com Telp: (021) 741-2566
Administrasi Bisnis (JAB), Vol. 21 No. 1 April 2015.

Pasaribu, V. L. D., Susanti, F., \& Hartuti, E. T. K. (2019). Memotivasi Siswa dan Siswi SMK Letris Indonesia di Dalam Menentukan Pilihan Untuk Melanjutkan Pendidikan Atau Bekerja Setelah Lulus Sekolah. Jurnal Pengabdian Dharma Laksana, 1(2), 161-172.

Pasaribu, V. L. D., Agrasadya, A., Shabrina, N., \& Krisnaldy, K. (2020). MENJADI ENTERPRENEUR MUDA YANG MEMILIKI JIWA LEADERSHIP UNTUK MENGHADAPI MASA DEPAN. Abdi Laksana, 1(1).

Pasaribu, V. L. D., Elburdah, R. P., Sudarso, E., \& Fauziah, G. (2020). PENGGUNAAN MANAJEMEN WAKTU TERHADAP PENINGKATAN PRESTASI BELAJAR DI SMP ARAISIYAH. Jurnal ABDIMAS Tri Dharma Manajemen, 1(1).

Pasaribu, V. L. D., Sulaiman, S., Sutiman, S., Thaharudin, T., \& Purnomo, B. Y. (2020). PENGENALAN LETAK POSYANDU TERDEKAT DIKELURAHAN PISANGAN DENGAN MANAJEMEN PEMASARAN REVOLUSI $\quad 4.0 \quad$ UNTUK MENINGKATKAN PENGETAHUAN MASYARAKAT LETAK DAN FUNGSI POSYANDU TERDEKAT PADA KELURAHAN PISANGAN. DEDIKASI PKM, 1(1), 105-110.

Pasaribu, V. L. D., Oktrima, B., Prabowo, B., Arianto, N., \& Haryoko, U. B. (2020). PROGAM PENDAMPINGAN DAN PENYELENGGARAAN PENDIDIKAN ANAK PADA USIA DINI TERHADAP PRESTASI

BELAJAR DILINGKUNGAN RT 020 RW 009. KEL GIRI PENI. KEC WATES. YOGYAKARTA. JURNAL LOKABMAS KREATIF, 1(1), 71-75.
RPIJM (Rencana Program Investasi Jangka Menengah) Bidang Cipta Karya Tahun 2019-2023. 2019. Tangerang Selatan. Bab 2.

Tambunan, Tulus .2000. Perkembangan Industri Skala Kecil di Indonesia, Jakarta: PT Mutiara Sumber Widya

Tambunan, Tulus. 2003. Perkembangan UMKM dalam Era AFTA: Peluang,Tantangan,

Permasalahan dan Alternatif Solusinya. Paper Diskusi pada Yayasan Indonesia Forum.

Tambunan, Tulus. 2012, Usaha Mikro Kecil dan Menengah di Indonesia: IsuIsu Penting. LP3ES

Undang Undang Republik Indonesia No.20, Usaha Mikro Kecil dan Menengah. 2008.

\section{DOKUMENTASI KEGIATAN}
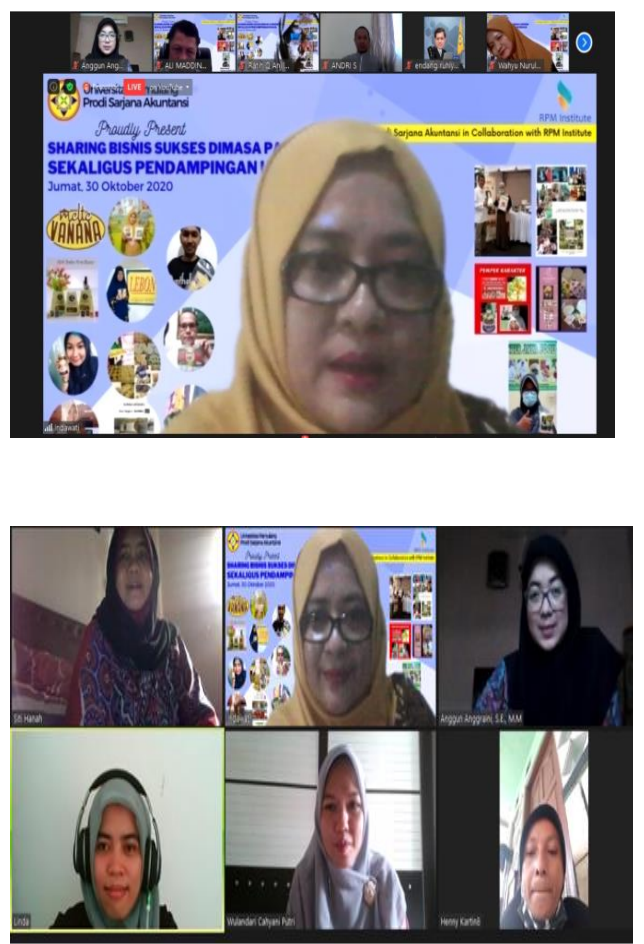